SECONDARY PLANT METABOLISM 


\section{SECONDARY PLANT METABOLISM}

Margaret L. Vickery and Brian Vickery 
All rights reserved. No part of this publication may be reproduced or transmitted, in any form or by any means, without permission.

First published 1981 by

THE MACMILLAN PRESS LTD

London and Basingstoke

Companies and representatives throughout the world

ISBN 978-0-333-27018-9 ISBN 978-1-349-86109-5 (eBook)

DOI 10.1007/978-1-349-86109-5

This book is sold subject to the standard conditions of the Net Book Agreement

The paperback edition of this book is sold subject to the condition that it shall not, by way of trade or otherwise, be lent, resold, hired out, or otherwise circulated without the publisher's prior consent in any form of binding or cover other than that in which it is published and without a similar condition including this condition being imposed on the subsequent purchaser. 


\section{CONTENTS}

Preface $\quad$ xi

$\begin{array}{lll}\text { Chapter } 1 \quad \text { Introduction } & 1\end{array}$

Primary and secondary metabolism $\quad 1$

The function of secondary metabolites $\quad 4$

The usefulness of secondary metabolites $\quad 6$

$\begin{array}{lr}\text { Secondary metabolites in chemosystematics } & 11\end{array}$

$\begin{array}{ll}\text { Plant tissue cultures } & 12\end{array}$

The investigation of biosynthetic pathways by isotopic tracer analysis 13

$\begin{array}{ll}\text { Bibliography } & 17\end{array}$

$\begin{array}{ll}\text { Chapter } 2 \quad \text { Sugar metabolism } & 20\end{array}$

$\begin{array}{ll}\text { Introduction } & 20\end{array}$

$\begin{array}{ll}\text { Photosynthesis } & 20\end{array}$

$\begin{array}{ll}\text { Monosaccharide derivatives } & 23\end{array}$

$\begin{array}{ll}\text { Myo-inositol } & 25\end{array}$

Ascorbic acid $\quad 30$

$\begin{array}{ll}\text { Glycosides } & 32\end{array}$

Storage carbohydrates $\quad 39$

$\begin{array}{ll}\text { Sucrose } & 39\end{array}$

$\begin{array}{ll}\text { Starch } & 41\end{array}$

Phytoglycogen $\quad 43$

$\begin{array}{ll}\text { Fructans } & 43\end{array}$

Mannans $\quad 44$

$\begin{array}{ll}\text { Exudate gums } & 45\end{array}$

Structural carbohydrates $\quad 46$

Plant cell walls $\quad 46$

$\begin{array}{lr}\text { Cellulose } & 47\end{array}$

Hemicelluloses $\quad 48$

$\begin{array}{lr}\text { D-Xylans } & 48\end{array}$

$\begin{array}{ll}\text { D-Mannans } & 49\end{array}$

L-Arabino-D-galactans $\quad 49$

$\begin{array}{ll}\text { Pectic substances } & 50\end{array}$

$\begin{array}{ll}\text { Pectin } & 50\end{array}$

Seaweed gums $\quad 51$

$\begin{array}{ll}\text { Alginic acid } & 52\end{array}$

$\begin{array}{ll}\text { Agar } & 52\end{array}$

$\begin{array}{ll}\text { Carrageenan } & 52\end{array}$

Carbohydrates in chemosystematics $\quad 53$

Bibliography $\quad 54$ 
Chapter 3 The acetate-malonate pathway

Introduction

Acetyl coenzyme A

The acetate-malonate pathway $\quad 58$

Fatty acid elongation systems $\quad 60$

The biosynthesis of hydroxy acids $\quad 62$

Catabolism of fatty acids $\quad 62$

B-Oxidation $\quad 62$

$\alpha$-Oxidation $\quad 65$

Lipoxygenase-catalysed oxidation $\quad 66$

Fatty acids in plants $\quad 68$

Plant lipids $\quad 73$

The function of plant lipids $\quad 76$

The economic importance of seed oils 78

Plant lipids in chemosystematics $\quad 79$

Polyacetylenes and thiophenes $\quad 81$

Polyacetylenes and thiophenes in chemosystematics 84

Bibliography $\quad 85$

$\begin{array}{lll}\text { Chapter } 4 & \text { Polyketides } & 88\end{array}$

Introduction $\quad 88$

The biosynthesis of polyketides $\quad 88$

Orsellinic acid $\quad 89$

6-Methylsalicylic acid $\quad 90$

Patulin and penicillic acid $\quad 91$

Griseofulvin $\quad 93$

Phloroglucinol derivatives $\quad 94$

Polyketides in lichens $\quad 96$

Quinones $\quad 97$

Aflatoxins 103

Fungal tropolones 103

Mycophenolic acid 104

Deviations in polyketide chain biosynthesis 105

The function and uses of polyketides 108

Polyketides in chemosystematics 109

Bibliography 110

Chapter $5 \quad$ The acetate-mevalonate pathway 112

Introduction $\quad 112$

Mevalonic acid 113

Dimethylallyl pyrophosphate $\quad 115$

Hemiterpenoids 116

Geranyl pyrophosphate and the monoterpenoids 117

Essential oils $\quad 119$

Iridoids $\quad 119$

Monoterpenoids with irregular structures $\quad 122$

Farnesyl pyrophosphate and the sesquiterpenoids 122

$\begin{array}{ll}\text { Abscisic acid } & 122\end{array}$ 
Geranylgeranyl pyrophosphate and the diterpenoids 124

Phytol 124

Gibberellins $\quad 126$

Squalene and the triterpenoids $\quad 127$

$\begin{array}{ll}\text { Triterpenoids } & 128\end{array}$

Metabolism of triterpenoids $\quad 132$

Cycloartenol and the steroids 133

Insect moulting hormones $\quad 137$

$\begin{array}{ll}\text { Sapogenins } & 137\end{array}$

Steroidal alkaloids $\quad 138$

$\begin{array}{ll}\mathrm{C}_{21} \text { steroids } & 140\end{array}$

Cardiac glycosides $\quad 141$

Steroid degradation $\quad 144$

Steroids in tissue cultures $\quad 145$

Carotenoids 146

Xanthophylls 148

Polyisoprenes 148

The function of terpenoids and steroids in plants 149

Terpenoids and steroids in chemosystematics $\quad 151$

Bibliography 154

$\begin{array}{lll}\text { Chapter } 6 & \text { Shikimic acid pathway metabolites } & 157\end{array}$

Introduction 157

The shikimic acid pathway $\quad 157$

Cinnamic acid derivatives 161

Benzoic acid derivatives 166

$\begin{array}{ll}\text { Lignin } & 168\end{array}$

Coumarins 171

Furanocoumarins 173

The hydrolysable tannins $\quad 175$

p-Aminobenzoic acid 177

The catabolism of shikimic acid pathway metabolites 177

The function of phenols in higher plants 178

Simple phenols, phenolic acids and coumarins in chemosystematics $\quad 180$

$\begin{array}{ll}\text { Bibliography } & 181\end{array}$

Chapter $7 \quad$ Compounds with a mixed biogenesis 183

Introduction $\quad 183$

Flavonoids $\quad 183$

Chalcones $\quad 184$

Aurones 186

Flavanones $\quad 187$

Flavones $\quad 187$

Flavonols 190

Flavanols 192

Proanthocyanidins $\quad 192$

Anthocyanins 194

Anthocyanin pigmentation $\quad 196$ 
Isoflavonoids

Catabolism of flavonoids

The function and physiological effects of plant flavonoids 203

Flavonoids in chemosystematics

Xanthones and stilbenes

Quinones

Benzoquinones

Ubiquinones, plastoquinones and tocopherols

208

Naphthoquinones

Phylloquinones and menaquinones

215

Anthraquinones

215

Quinones in chemosystematics

Bibliography

Chapter $8 \quad$ Compounds derived from amino acids

Introduction

Non-protein amino acids

3-Cyanoalanine

Mimosine

$N^{3}$-Oxalyldiaminopropionic acid

Canavanine

Azetidine-2-carboxylic acid

Selenoamino acids

Non-protein amino acids in chemosystematics

Amines

3-Aminopropionitrile

Polyamines

Histamine

Protoalkaloids

234

Amines in chemosystematics

Colchicine

Cyanogenic glycosides and cyanolipids

Cyanogenic glycosides

Cyanolipids

Cyanogenic glycosides in chemosystematics

Glucosinolates

Glucosinolates in chemosystematics

Penicillins and cephalosporins

Sulphur compounds derived from cysteine

3-Indolylacetic acid

Ethylene

Bibliography 
$\begin{array}{ll}\text { The pyrrolizidine alkaloids } & 260\end{array}$

$\begin{array}{ll}\text { Alkaloids biosynthesised from lysine } & 263\end{array}$

$\begin{array}{ll}\text { The piperidine alkaloids } & 263\end{array}$

The lupin alkaloids $\quad 264$

$\begin{array}{ll}\text { Cytisine } & 266\end{array}$

$\begin{array}{ll}\text { Alkaloids biosynthesised from nicotinic acid } & 267\end{array}$

$\begin{array}{ll}\text { The tobacco alkaloids } & 267\end{array}$

$\begin{array}{ll}\text { Alkaloids biosynthesised from tyrosine } & 269\end{array}$

$\begin{array}{ll}\text { The benzylisoquinoline alkaloids } & 270\end{array}$

$\begin{array}{ll}\text { Alkaloids biosynthesised from tyrosine and phenylalanine } & 273\end{array}$

$\begin{array}{ll}\text { The phenanthridine alkaloids } & 273\end{array}$

$\begin{array}{ll}\text { Alkaloids biosynthesised from tryptophan } & 275\end{array}$

$\begin{array}{ll}\text { The simple indole alkaloids } & 275\end{array}$

$\begin{array}{ll}\text { Physostigmine } & 276\end{array}$

$\begin{array}{ll}\text { The ergot alkaloids } & 277\end{array}$

The complex indole alkaloids $\quad 279$

Strychnine $\quad 283$

Quinine $\quad 284$

Alkaloids in tissue cultures $\quad 284$

$\begin{array}{ll}\text { Alkaloids in chemosystematics } & 284\end{array}$

$\begin{array}{ll}\text { Bibliography } & 287\end{array}$

$\begin{array}{lll}\text { Chapter } 10 & \text { Porphyrins, purines and pyrimidines } & 289\end{array}$

Introduction $\quad 289$

$\begin{array}{ll}\text { Porphyrins } & 289\end{array}$

Purine and pyrimidine derivatives 293

The biosynthesis of purines and pyrimidines $\quad 293$

$\begin{array}{ll}\text { Nucleotides } & 296\end{array}$

$\begin{array}{ll}\text { Nucleic acids } & 300\end{array}$

The catabolism of nucleic acids $\quad 302$

Nucleic acids in plant chemosystematics 306

$\begin{array}{ll}\text { Bibliography } & 307\end{array}$

$\begin{array}{ll}\text { General Index } & 309\end{array}$

Chemical Index $\quad 314$

$\begin{array}{ll}\text { Botanical Index } & 328\end{array}$ 


\section{PREFACE}

Considerable advances in the understanding of secondary metabolism in plants have been made over the past decade. Elucidation of the biosynthetic pathways of secondary metabolites is continuing apace, and, while their function is still open to controversy, it is now widely acknowledged that these compounds are not the metabolic waste products they were once thought to be.

While we have endeavoured to include the most recent results reported in the literature of plant biochemistry, such is the volume of research being undertaken in this subject that the reader is recommended to consult the continuing journals listed in the bibliographies at the end of each chapter to keep abreast of developments in secondary plant metabolism. In particular, subsequent volumes of the Chemical Society's Biosynthesis will, it is hoped, continue to give a good coverage of the subject.

Exciting discoveries are continually being made in the field of secondary plant metabolism. Since completion of the manuscript of this book, it has been reported that not only can plants biosynthesise vitamin $\mathrm{D}_{3}$ (cholecalciferol), once assumed the exclusive preserve of vertebrates, but the biosynthetic pathways forming this compound are similar in both plants and animals.

The overall purpose of our book, Secondary Plant Metabolism, is to show that plants do not haphazardly produce a large number of chemical compounds, but that each metabolite is biosynthesised for a definite purpose (although we may not, as yet, have discovered this purpose), and that all products are interrelated according to a complex plan which conserves energy and scarce inorganic nutrients. The format of the book is based on five main biosynthetic routes, namely sugar metabolism, the acetate-malonate pathway, the acetate-mevalonate pathway, the shikimic acid pathway, and metabolites derived from amino acids. An introductory chapter attempts to define primary and secondary metabolism, although in the light of modern work, it is no longer logical to make a clear-cut separation of the two. This chapter also discusses possible functions of secondary metabolites and describes some of the more important uses that man has made of these compounds. A brief introduction to isotopic tracer analysis is included, as this is the tool which more than any other has led to the elucidation of many of the sequences of secondary metabolite biosynthesis. Enzymology is not included, although the isolation and characterisation of the enzymes catalysing a particular biosynthetic step are the only means of proving that such a step takes place. This subject is usually well covered in any good book of biochemistry, however, and it would be superfluous to repeat the information here.

Many attempts have been made using secondary metabolites in the classification of plants, which is traditionally based on morphology. Such attempts have had some success and brief descriptions of examples are included at the end of each chapter or section. 
Although this book is mainly concerned with biosynthesis, no description of secondary metabolites would be complete without reference to the ways in which these compounds affect animals, insects and other plants. Such ecological properties are therefore briefly included wherever applicable.

University of Warwick, 1980

M.L.V.

B.V. 